\title{
(Hydroxyphenyl)oxazoline: A Novel and Remarkably Facile Entry into the Area of Chiral Cationic Alkylzirconium Complexes Which Serve as Polymerization Catalysts
}

\author{
Pier Giorgio Cozzi, ${ }^{\dagger}$ Emma Gallo, and Carlo Floriani* \\ Institut de Chimie Minérale et Analytique, BCH, Université de Lausanne, \\ CH-1015 Lausanne, Switzerland \\ Angiola Chiesi-Villa and Corrado Rizzoli \\ Dipartimento di Chimica, Università di Parma, I-43100 Parma, Italy
}

Received June 27, $1995^{\circledR}$

\begin{abstract}
Summary: How can the entry into the area of chiral cationic alkyl derivatives of group 4 metals be simplified? We succeeded in using readily available amino alcohols, which have been converted into chiral (hydroxyphenyl)oxazolines. These compounds have been employed in the organometallic derivatization of early transition metals.
\end{abstract}

The widespread study of cationic zirconocene alkyl complexes, $\mathrm{Cp}_{2} \mathrm{Zr}(\mathrm{R})^{+}$, stens from the use of these electrophilic $\mathrm{d}^{0}$ species in both stoichiometric ${ }^{1}$ and catalytic $^{2}$ reactions, especially $\alpha$-olefin polymerization. ${ }^{3}$ The extensive range of modified $\mathrm{Cp}$ ligands all serve to force incoming substrate molecules toward a vacant coordination site cis to the $\mathrm{M}-\mathrm{R}$ bond in the so-called equatorial binding plane. However, such ligands are rarely accessible via facile, large-scale syntheses. ${ }^{4}$ Con-

\footnotetext{
* To whom correspondence should be addressed.

† Present address: Istituto di Chimica "G. Ciamician", Università di Bologna, I-40216 Bologna, Italy.

A Abstract published in Advance ACS Abstracts, October 15, 1995 (1) Collins, S.; Kuntz, B. A.; Collins, S. J. Org. Chem. 1989, 54, 4154 Jordan, R. F. Adv. Organomet. Chem. 1991, 32, 325. Grossman, R. B. Davis, W. M.; Buchwald, S. L. J. Am. Chem. Soc. 1991, 113, 2321. Guram, A. S.; Swenson, D. C.; Jordan, R. F. J. Am. Chem. Soc. 1982, 114, 8991. Guram, A. S.; Guo, Z.; Jordan, R. F. J. Am. Chem. Soc. 1993 115, 4902. Guram, A. S.; Jordan, R. F. J. Org. Chem. 1993, 58, 5595. Hong, Y.; Kuntz, B. A.; Collins, S. Organometallics 1993, 12, 964.

(2) Pino, P.; Cioni, P.; Wei, J. J. Am. Chem. Soc. 1987, 109, 6189. Waymouth, R. M.; Pino, P. J. Am. Chem. Soc. 1990, 112, 4911. Morken J. P. Didiuk, M. T. Hoveyda, A. H. J. Am. Chem. Soc. 1993, 115, 6997. Rodewald, S.; Jordan, R. F. J. Am. Chem. Soc. 1994, 116, 4491 and references therein.

(3) Kaminsky, W; Külper, K. Brintzinger, H. H.; Wild, F. R. W. P. Angew. Chem., Int. Ed. Engl, 1985, 24, 507. Ewen, J. A.; Haspeslagh L.; Atwood, J. L.; Zhang, H. J. Am. Chem. Soc. 1987, 109, 6544. Ewen, J. A.; Jones, R. L.; Razavi, A.; Ferrara, J. D. J. Am. Chem. Soc. 1988, 110, 6255. Hlatky, G. G.; Turner, H. W. Eckman, R. R. J Am. Chem Soc. 1989, 111, 2728. Yang, X.; Stern, C. L.; Marks, T. J. Am. Chem. Soc. 1991, 113, 3623. Collins, S.; Gauthier, W. J.; Holden, D. A.; Kuntz B. A.; Taylor, N. J.; Ward, D. G. Organometallics 1991, 10, 2061. Resconi, L.; Piemontesi, F.; Franciscano, L.; Abis, L.; Fiorani, T. $J$ Am. Chem. Soc. 1992, 114, 1025. Burger, P.; Diebold, J.; Gutmann S.; Hund, H. U.; Brintzinger, H. H. Organometallics 1992, 11, 1319. Marks, T. Acc. Chem. Res. 1992, 25, 57. Coates, G. W.; Waymouth, R. M. J. Am. Chem. Soc. 1993, 115, 91. Erker, G.; Aulbach, M.; Knickmeier, M.; Wingbermühle, D.; Krüger, C.; Nolte, M.; Werner, S. J. Am Chem. Soc. 1993, 115, 4590. Guerra, G.; Cavallo, L.; Moscardi, G.; Vacatello, M.; Corradini, P. J. Am. Chem. Soc. 1994, 116, 2988. Yang, X.; Stern C. L.; Marks, T. J. J. Am Chem. Soc. 1994, $116,10015$.

(4) Hollis, K. T; Rheingold, A. L.; Robinson, N. P.; Whelan, J Bosnich, B. Organometallics 1992, 11, 2812. Huttenloch, M.; Diebold, J.; Rief, U.; Brintzinger, H. H.; Gilbert, A. M.; Katz, T. J. Organometallics 1992, 11, 3600. Ellis, W. W.; Hollis, K. T.; Odenkirk, W.; Whelan, J.; Ostrander, R.; Rheingold, A. L.; Bosnich, B. Organometallics 1993 12, 4391. Herrmann, W. A.; Anwander, R.; Riepl, H.; Scherer, W.; Whitaker, C. R. Organometallics 1993, 12, 4342. Rieger, B.; Jany, G. Fawzi, R.; Steimann, M. Organometallics 1994, 13, 647.
}

sequently, there is a growing interest in the use of other non-Cp-based ligands as ancillary fragments for highoxidation-state group 4 metals. Previously we have investigated the use of dibenzotetramethyltetraaza[14]annulene, tmtaa, as just such an ancillary ligand, ${ }^{5}$ and Jordan and co-workers have prepared the corresponding cationic alkyls, tmtaaZr $(R)^{+} .6$ Although these complexes display a disappointingly low activity for the Ziegler-Natta polymerization of $\alpha$-olefins, they nevertheless exhibit interesting insertion chemistry and can promote intramolecular $\mathrm{C}-\mathrm{H}$ activation.

We have since turned our attention toward the (hydroxyphenyl)oxazoline ligand and recently reported the synthesis and structures of dichlorobis(hydroxyphenyl)oxazolinato)titanium(IV) and -zirconium(IV), ${ }^{7}$ [L $\left.\mathrm{L}_{2} \mathrm{MCl}_{2}\right]$ ( $\mathrm{L}=$ (hydroxyphenyl)oxazolinato anion). Herein, we communicate organometallic derivatives of $\left[\mathrm{L}_{2} \mathrm{MCl}_{2}\right](\mathrm{M}=\mathrm{Zr}$, Hf). These initial explorations have focused upon the achiral $1^{8}$ and the chiral $2^{8}$ and $3^{8}$ ligands, which are readily accessible on a large scale from commercially available amino alcohols.

Reaction of $\left[\mathrm{L}_{2} \mathrm{MCl}_{2}\right](\mathrm{L}=1-3)$ with organolithium $(\mathrm{MeLi})$ or organomagnesium $(\mathrm{MeMgBr})$ reagents does not lead to the desired dialkyl complexes. However, direct alkane elimination arising from the reaction of 1-3 with $\mathrm{M}\left(\mathrm{CH}_{2} \mathrm{Ph}\right)_{4}$ gives the bis(benzyl) complexes 4-7 in good yields (typically $60-70 \%$ ). ${ }^{9}$

In order to investigate the orientation and bonding mode of the benzyl ligands the crystal structure of 4 was determined. ${ }^{10}$ Room-temperature ${ }^{1} \mathrm{H}$ NMR suggests that in solution 4 contains two $\eta^{1}-\mathrm{CH}_{2} \mathrm{Ph}$ ligands

(5) (a) Ciurli, S.; Floriani, C.; Chiesi-Villa, A.; Guastini, C. J. Chem. Soc., Chem. Commun. 1986, 1401. (b) Floriani, C.; Ciurli, S.; ChiesiVilla, A.; Guastini, C. Angew. Chem., Int. Ed. Engl. 1987, 26, 70. (c) Floriani, C.; Mazzanti, M.; Ciurli, S.; Chiesi-Villa, A.; Guastini, C. J. Chem. Soc., Dalton Trans. 1988, 1361. (d) Solari, E.; De Angelis, S.; Floriani, C.; Chiesi-Villa, A.; Rizzoli, C. Inorg. Chem. 1992, 31, 96. (e) De Angelis, S.; Solari, E.; Gallo, E.; Floriani, C.; Chiesi-Villa, A.; Rizzoli, C. Inorg. Chem. 1992, 31, 2520. (f) Giannini, L.; Solari, E.; Floriani, C.; Chiesi-Villa, A.; Rizzoli, C. Angew. Chem., Int. Ed. Engl. 1994, 33, 2204. (g) Goedken, V. L.; Ladd, J. A. J. Chem. Soc., Chem. Commun. 1981, 910; 1982, 142. (h) Housmekerides, C. E.; Pilato, R. S.; Geoffroy, G. L.; Rheingold, A. L. J. Chem. Soc., Chem. Commun, 1991, 563. (i) Yang, C. H.; Ladd, J. A.; Goedken, V. L. J. Coord. Chem. 1988, 18, 317. (j) Floriani, C. Polyhedron 1989, 8, 1717

(6) Uhrhammer, R.; Black, D. G.; Gardner, T. G.; Olsen, J. D.; Jordan, R. F. J Am. Chem. Soc, 1993, 115, 8493.

(7) Cozzi, P. G.; Floriani, C.; Chiesi-Villa, A.; Rizzoli, C. Inorg. Chem. 1995, 34, 2921.

(8) Bolm, C.; Weickhardt, K.; Zehnder, M.; Ranff, T. Chem. Ber. $1991,124,1173$. 


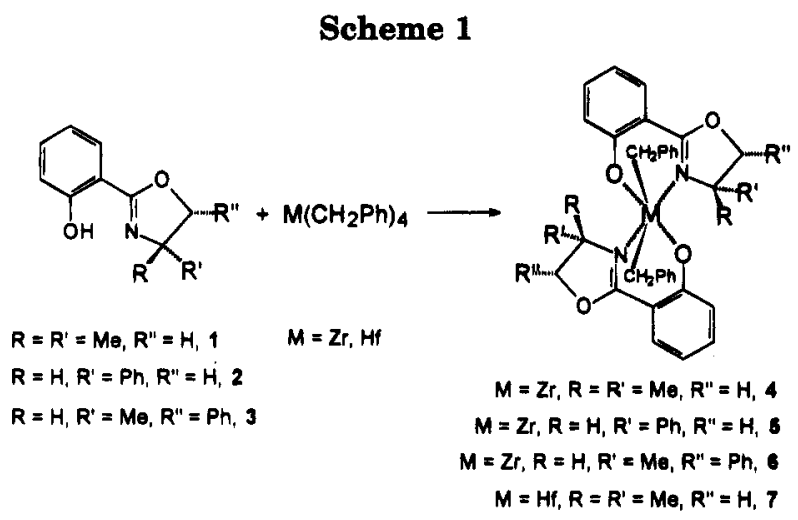

(indicated by the absence of the high-field shifts for the ortho protons and $\mathrm{AB}$ splitting pattern for the diastereotropic methylene protons), and such a proposal is confirmed by the X-ray study (Figure 1). The molecule possesses a crystallographic $C_{2}$ symmetry. The two symmetry-related oxazolinato ligands, which are almost planar, are nearly mutually orthogonal (dihedral angles 96.6(1) and $\left.102.4(1)^{\circ}\right)$, resulting in a distorted-octahedral coordination around zirconium completed by the carbon atoms from two benzylic groups. The bond angles $\mathrm{Zr}-\mathrm{C} 18-\mathrm{C} 12\left(113.7(3)\right.$ and $\left.113.4(3)^{\circ}\right)$ are typical of the $\eta^{1}$ coordination mode. This observation is initially surprising in view of the electron-deficient nature of the metal center. We assume that 5-7 adopt similar structures.

Complexes 8-10 ${ }^{11-13}$ could be prepared from 4,5 , and 7 via a protonolysis reaction with $\left(\mathrm{HNMe}_{2} \mathrm{Ph}\right)\left(\mathrm{BPh}_{4}\right)$,

(9) To a stirred suspension of $\mathrm{M}\left(\mathrm{CH}_{2} \mathrm{Ph}\right)_{4}(\mathrm{M}=\mathrm{Zr}$, Hf $)(6-15 \mathrm{mmol})$ in $\mathrm{Et}_{2} \mathrm{O}$ was added an $\mathrm{Et}_{2} \mathrm{O}$ solution of the ligand $(1,2$, or 3); $12-30$ $\mathrm{mmol}$ ) in a dropwise fashion at $-40^{\circ} \mathrm{C}$. The solution was then warmed to room temperature. For complexes 4,5 , and 7 , the reaction mixture was partially concentrated and the yellow-orange solid was filtered and collected. Complex 6 was prepared with the same method except for the utilization of toluene instead of $\mathrm{Et}_{2} \mathrm{O}$. The solvent was removed, and pentane was added. The resulting orange oil was scraped with a spatula under nitrogen until a solid was obtained, which was quickly filtered. 4: ${ }^{1} \mathrm{H}$ NMR $\left(\mathrm{C}_{6} \mathrm{D}_{6}, \mathrm{ppm}\right) \delta 7.85$ (dd, $2 \mathrm{H}, J=1.41,7.89 \mathrm{~Hz}$ ) $7.16(\mathrm{dt}, 2 \mathrm{H}, J=1.55,8.67 \mathrm{~Hz}), 7.06-6.95(\mathrm{~m}, 22 \mathrm{H}), 6.71$ (dt, $2 \mathrm{H}, J$ $=0.97,8.05 \mathrm{~Hz}), 3.24(\mathrm{~s}, 4 \mathrm{H}), 2.66(\mathrm{AB}, 4 \mathrm{H}, J=10.34 \mathrm{~Hz}), 1.29(\mathrm{~s}$, $6 \mathrm{H}), 0.52(\mathrm{~s}, 6 \mathrm{H})$. IR: $1607,1580,1550 \mathrm{~cm}^{-1}$. Anal. Calcd for $\mathrm{C}_{36} \mathrm{H}_{38} \mathrm{~N}_{2} \mathrm{O}_{4} \mathrm{Zr}: \mathrm{C}, 66.13 ; \mathrm{H}, 5.81 ; \mathrm{N}, 4.28$. Found: C, 66.14; $\mathrm{H}, 6.13$; $\mathrm{N}, 4.39$. Analytical and spectroscopic data for 5-7 are given in the Supporting Information.

(10) Crystal data for 4: $\mathrm{C}_{36} \mathrm{H}_{38} \mathrm{~N}_{2} \mathrm{O}_{4} \mathrm{Zr}$, monoclinic, space group $P 2 /$ $c ; a=22.254(1) \AA, b=9.199(1) \AA, c=16.842(2) \AA, \beta=110.34(1)^{\circ}, V$ $=3232.8(6) \AA^{3}, Z=4, \rho_{\text {calcd }}=1.344 \mathrm{~g} \mathrm{~cm}^{-3}$; Cu Ka radiation $(\lambda=$ $1.54178 \AA), \mu(\mathrm{Cu} \mathrm{K} \alpha)=31.27 \mathrm{~cm}^{-1}$; crystal dimensions $0.16 \times 0.31 \times$ $0.39 \mathrm{~mm}$. The structure was solved by the heavy-atom method and anisotropically refined for all the non-hydrogen atoms. The hydrogen atoms were located from a difference map and introduced as fixed contributors in the last stage of refinement $\left(U_{\text {iso }}=0.10 \AA^{2}\right)$. For 4168 unique observed reflections $(I>2 \sigma(I)$ ), collected at $295 \mathrm{~K}$ on a Rigaku AFC6S diffractometer $\left(6<2 \theta<140^{\circ}\right)$ and corrected for absorption, the final conventional $R$ was 0.040 (wR2 $=0.103$ ). In the unit cell there are two crystallographically independent half-molecules (A and B, Figures 1 and S1 (Supporting Information)) related by a pseudo center of symmetry. Attempts to transform the starting unit cell to a higher symmetry one were unsuccessful. The data reported refer to molecule A See the Supporting Information for more details.

(11) Preparation of 8: to a solution of complex $4(1.42 \mathrm{~g}, 2.173 \mathrm{mmol})$ in THF $(60 \mathrm{~mL})$ at $-78^{\circ} \mathrm{C},(\mathrm{cp})_{2} \mathrm{Fe}^{+} \mathrm{BPh}_{4}{ }^{-}$in one portion, and the resulting slurry was warmed to room temperature. After a few minutes the blue of the ferrocenium cation disappeared and a yellow compound started to precipitate. The mixture was stirred for $2 \mathrm{~h}$ at room temperature, and the orange-yellow compound was collected, washed with $\mathrm{Et}_{2} \mathrm{O}(35 \mathrm{~mL})$, and dried under vacuum. The cationic complex was recrystallized in a dichloroethane-THF mixture (46\%). ${ }^{1} \mathrm{H}$ NMR $\left(\mathrm{CD}_{2} \mathrm{C}_{12} \mathrm{ppm}\right): \delta 7.95(\mathrm{dd}, 2 \mathrm{H}, J=1.71,7.89 \mathrm{~Hz}), 7.72(\mathrm{dt}, 2 \mathrm{H}, J=$ $2.06,6.54 \mathrm{~Hz}), 7.45-6.7(\mathrm{~m}, 29 \mathrm{H}), 4.13\left(\mathrm{AB}, 4 \mathrm{H}, J=8.91 \mathrm{~Hz}^{2}, \mathrm{OCH}_{2}\right)$; $2.65\left(\mathrm{AB}, 2 \mathrm{H} ; J=10.29 \mathrm{~Hz}, \mathrm{CH}_{2} \mathrm{Ph}\right), 3.78\left(\mathrm{~m}, 6 \mathrm{H}, \mathrm{THF}, \mathrm{CH}_{2} \mathrm{ClCH}_{2}\right.$ $\mathrm{Cl}, 1.81(\mathrm{~m}, 4 \mathrm{H}, \mathrm{THF}) ; 1.44(\mathrm{~s}, 6 \mathrm{H}, \mathrm{Me}) ; 0.99(\mathrm{~s}, 6 \mathrm{H}, \mathrm{Me})$. IR: 1603 $1578,1545 \mathrm{~cm}^{-1}$. Anal. Calcd for $\mathrm{C}_{55.5} \mathrm{H}_{56} \mathrm{BCl}_{0.5} \mathrm{~N}_{2} \mathrm{O}_{4.5} \mathrm{Zr}$ : C, $70.71 ; \mathrm{H}$, $5.94 ; \mathrm{N}, 2.97$. Found: C, 70.64; H, 6.64; N, 2.99 .

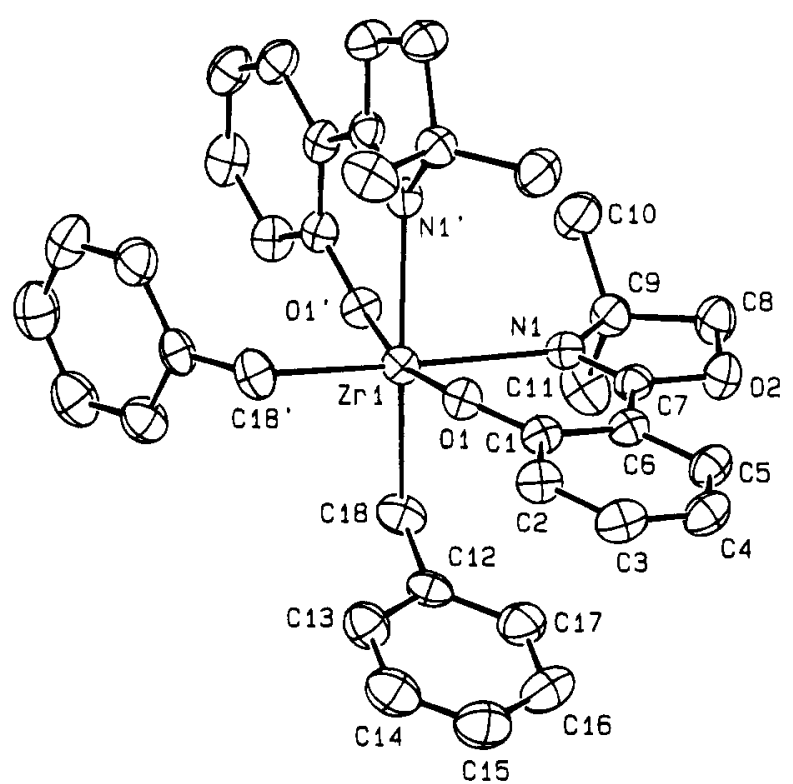

Figure 1. ORTEP drawing of molecule $A$ in complex 4 (30\% probability ellipsoids). Selected bond distances $(\AA)$ and angles (deg) (values in brackets refer to molecule $B$ ): $\mathrm{Zr1}-01,2.001(3)[2.007(4)] ; \mathrm{Zr} 1-\mathrm{N} 1,2.398(4)$ [2.401(4)]; $\mathrm{Zr} 1-\mathrm{C} 18,2.294(5)[2.280(5)] ; \mathrm{O} 1-\mathrm{C} 1,1.333(4)[1.315(6)]$; $\mathrm{O} 2-\mathrm{C} 7,1.350(5)[1.340(6)] ; \mathrm{O} 2-\mathrm{C} 8,1.450(6)[1.429(9)] ;$ $\mathrm{N} 1-\mathrm{C} 7,1.294(4)$ [1.290(7)]; N1-C9, 1.513(6) [1.507(6)]; $\mathrm{C} 18-\mathrm{Zr} 1-\mathrm{C} 18^{\prime}, 96.8(2)$ [94.1(2)]; N1-Zr1-C18', 167.3(1) [167.0(1)]; N1-Zr1-C18, 89.7(1) [89.6(1)]; O1-Zr1-C18', 91.3(1) [90.9(1)]; O1-Zr1-C18, 97.4(1) [99.9(2)]; O1-Zr1$\mathrm{N1}^{\prime}, 93.3(1)[92.5(1)] ; \mathrm{O} 1-\mathrm{Zr} 1-\mathrm{N} 1,77.0(1)$ [76.2(1)]; O1$\mathrm{Zr} 1-\mathrm{O} 1^{\prime}, 166.9(1)$ [164.1(1)]; $\mathrm{Zr}-\mathrm{O} 1-\mathrm{C} 1,141.8(3)$ [145.0(3)]; $\mathrm{Zr} 1-\mathrm{C} 18-\mathrm{C} 12,113.7(3)$ [113.4(3)]. The prime denotes transformations of $1-x, y,-0.5-z$ for molecule $\mathrm{A}$ and $-x, y, 0.5-z$ for molecule $\mathrm{B}$, respectively.

$\left(\mathrm{HNEt}_{3}\right)\left(\mathrm{BPh}_{4}\right)$, or $\left(\mathrm{HNBu}_{3}\right)\left(\mathrm{BPh}_{4}\right)$ or, more conveniently, in a number of cases by oxidative cleavage using $\mathrm{Cp}_{2} \mathrm{FeBPh}_{4} \cdot{ }^{14}$

(12) Preparation of 9: to a stirred solution of complex 5 (2.915 g $3.74 \mathrm{mmol})$ in THF $(80 \mathrm{~mL})$ at $-78^{\circ} \mathrm{C}$ was added $(\mathrm{cp})_{2} \mathrm{Fe}^{+} \mathrm{BPh}_{4}-(1.98$ g $3.74 \mathrm{mmol}$ ) was added in one portion. The blue solution was immediately warmed to room temperature. The solution turned orange, and it was stirred for $1 \mathrm{~h}$ at room temperature. The solvent was pumped off, and $\mathrm{Et}_{2} \mathrm{O}(50 \mathrm{~mL})$ was added to the remaining solid. The yellow suspension was stirred for $1 \mathrm{~h}$ at room temperature and filtered; the residue was washed with $\mathrm{Et}_{2} \mathrm{O}(20 \mathrm{~mL})$ and dried under vacuum $(80 \%) .{ }^{1} \mathrm{H} \mathrm{NMR}\left(\mathrm{CD}_{2} \mathrm{Cl}_{2}, \mathrm{ppm}\right): \delta 8.1(\mathrm{br}, 2 \mathrm{H}), 7.7(\mathrm{t}, 2 \mathrm{H}, J=6.5 \mathrm{~Hz})$ 7.4-6.8 (m, $41 \mathrm{H}) ; 5.75(\mathrm{br}, 2 \mathrm{H}), 4.5-4.0(\mathrm{br}, 4 \mathrm{H}), 1.89(\mathrm{br}, 2 \mathrm{H}), 0.8$ (br, $6 \mathrm{H})$. IR: $1602.9,1572.2,1545.5 \mathrm{~cm}^{-1} \cdot[\alpha]_{\mathrm{D}}{ }^{23}=+34.3(c=2.36$, $\mathrm{CH}_{2} \mathrm{Cl}_{2}$ ). Anal. Calcd for $\mathrm{C}_{75} \mathrm{H}_{85} \mathrm{BN}_{2} \mathrm{O}_{7} \mathrm{Zr}$ : $\mathrm{C}, 73.34 ; \mathrm{H}, 6.92 ; \mathrm{N}, 2.28$. Found: C, $73.06 ; \mathrm{H}, 6.18 ; \mathrm{N}, 2.3$.

(13) Preparation of 10 : to a stirred solution of $7(1.05 \mathrm{~g}, 1.42 \mathrm{mmol})$ in THF $(70 \mathrm{~mL})$ at $-78^{\circ} \mathrm{C}$ was added $\mathrm{HEt}_{3} \mathrm{~N}^{+} \mathrm{BPh}_{4}{ }^{-}(0.58 \mathrm{~g} .1 .38 \mathrm{mmol})$ in one portion, and the mixture was warmed to room temperature. After a few minutes, the ammonium salt was dissolved and an orangeyellow solution was obtained. The solution was stirred for $2 \mathrm{~h}$ at room temperature; then the THF was pumped off. $\mathrm{Et}_{2} \mathrm{O}$ was added $(60 \mathrm{~mL})$, and the mixture was stirred for $1 \mathrm{~h}$ at room temperature and then filtered. The collected solid was washed with $\mathrm{Et}_{2} \mathrm{O}(20 \mathrm{~mL})$ and dried under vacuum $(75 \%)$. ${ }^{1} \mathrm{H}$ NMR $\left(\mathrm{CD}_{2} \mathrm{Cl}_{2}\right.$, room temperature, ppm): $\delta$ 7.98 (dd, $2 \mathrm{H}, J=2.06,8.23 \mathrm{~Hz}), 7.73(\mathrm{dt}, 2 \mathrm{H}, J=1.72,7.24 \mathrm{~Hz})$, 7.4-6.6 (m, $29 \mathrm{H}), 4.18\left(\mathrm{br}, 4 \mathrm{H}\right.$, OCH $\left.{ }_{2}\right), 3.92(\mathrm{br}, 4 \mathrm{H}, \mathrm{THF}), 2.16(\mathrm{~s}$, $2 \mathrm{H} \mathrm{CH} \mathrm{Ph}, 177(\mathrm{~m}, 4 \mathrm{H}$, THF), $16(\mathrm{br}, 6 \mathrm{H}, \mathrm{Me}) 10(\mathrm{br}, 6 \mathrm{H}, \mathrm{Me})$. ${ }^{1} \mathrm{H}$ NMR $\left(\mathrm{CD}_{2} \mathrm{Cl}_{2}, 213 \mathrm{~K}, \mathrm{ppm}\right): \delta 7.98(\mathrm{dd}, 2 \mathrm{H}, j=2.06,8.23 \mathrm{~Hz})$, $7.73(\mathrm{dt}, 2 \mathrm{H}, J=1.72,7.24 \mathrm{~Hz}), 7.7-6.6(\mathrm{~m}, 29 \mathrm{H}), 4.34(\mathrm{~d}, 1 \mathrm{H}, J=$ $9 \mathrm{~Hz}), 4.22(\mathrm{~d}, 1 \mathrm{H}, J=9 \mathrm{~Hz}), 4.18(\mathrm{~d}, 1 \mathrm{H}, J=9 \mathrm{~Hz}), 4.13(\mathrm{~d}, 1 \mathrm{H}, J$ $=9 \mathrm{~Hz}), 3.99(\mathrm{br}, 2 \mathrm{H}, \mathrm{THF}), 3.85(\mathrm{br}, 2 \mathrm{H}, \mathrm{THF}), 2.18(\mathrm{~d}, 1 \mathrm{H}, J=12$ $\mathrm{Hz}), 2.03(\mathrm{~d}, 1 \mathrm{H}, J=12 \mathrm{~Hz}), 1.76\left(\mathrm{~s}, 3 \mathrm{H}, \mathrm{CH}_{3}\right), 1.67(\mathrm{br}, 4 \mathrm{H}, \mathrm{THF})$, $1.39\left(\mathrm{~s}, 3 \mathrm{H}, \mathrm{CH}_{3}\right), 0.95\left(\mathrm{~s}, 3 \mathrm{H}, \mathrm{CH}_{3}\right), 0.86\left(\mathrm{~s}, 3 \mathrm{H}, \mathrm{CH}_{3}\right)$. IR: 1604 $1576,1533 \mathrm{~cm}^{-1}$. Anal. Calcd for $\mathrm{C}_{57} \mathrm{H}_{59} \mathrm{BHAN}_{2} \mathrm{O}_{5}: \mathrm{C}, 65.7 ; \mathrm{H}, 5.67 ; \mathrm{N}$, 2.69. Found: C, 64.78; H, 5.91; N, 2.77 .

(14) Jordan, R. F.; La Pointe, R. E.; Bradley, P. K.; Baenziger, N C. Organometallics 1989, 8, 2892. 
Scheme 2

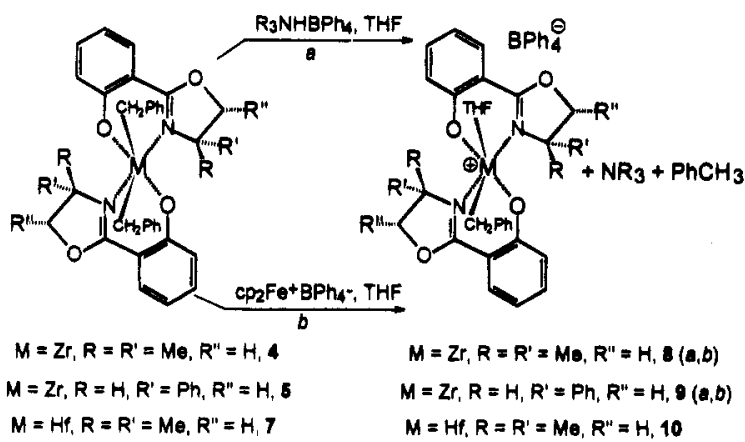

The characterization of 8-10 has been carried out by standard techniques, including an X-ray analysis of 10.THF. ${ }^{15}$ In this context we should mention that the ${ }^{1} \mathrm{H}$ NMR spectrum of 10 showed some nonstereorigidity of the complex, revealed by the broad resonances observed for the substituents of the oxazoline ring at $298 \mathrm{~K}$, which sharpened on lowering the temperature to $213 \mathrm{~K}$. Coordination around hafnium, shown in Figure 2, is distorted octahedral, closely resembling that of complex 4, the two chelating oxazolinato ligands being mutually orthogonal (dihedral angle $90.0(3)^{\circ}$ ). Coordination is completed by a carbon atom from a $\eta^{1}$-benzylic group and an oxygen atom from a THF group. ${ }^{16}$ The best equatorial plane is defined by the $\mathrm{O} 1, \mathrm{~N} 2, \mathrm{O} 3, \mathrm{O} 5$ atoms (maximum displacement 0.095(14) $\AA$ for O3), hafnium being displaced by $0.161(2) \AA$ toward the $C 47$ benzylic carbon. There is no major structural difference between 4 and 10. The structural parameters (i.e. $\mathrm{M}-\mathrm{O}$ and $\mathrm{M}-\mathrm{N}$ bond distances and associated angles) do not allow us to take into account a significant $\pi$-interaction of the zirconium with the donor atoms of the ligand, as a support for the rather low acidity shown by the reactivity of the cationic species. A nonsolvated form of 8-10 is expected to have a much higher reactivity. In fact, 8 , when generated in toluene solution (pathway a), does serve as an initiator for the polymerization of ethylene without the need for a cocatalyst, albeit of low activity. ${ }^{17}$

In conclusion, we have demonstrated that chiral, cationic $\mathrm{d}^{0}$ species based on readily prepared and easily

(15) Crystal data for 10: $\mathrm{C}_{33} \mathrm{H}_{39} \mathrm{HfN}_{2} \mathrm{O}_{5} \cdot \mathrm{C}_{24} \mathrm{H}_{20} \mathrm{~B}_{3} \cdot \mathrm{C}_{4} \mathrm{H}_{8} \mathrm{O}$, monoclinic, space group $P 2 / c ; a=10.874(6) \AA, b=37.008(8) \AA, c=13.952(6) \AA, \beta$ $=106.54(3)^{\circ}, V=5382(4) \AA^{3}, Z=4, \rho_{\text {caled }}=1.374 \mathrm{~g} \mathrm{~cm}^{-3} ; \mathrm{Cu} \mathrm{Ka}$ radiation $(\lambda=1.54178 \AA), \mu(\mathrm{Cu} \mathrm{K} \alpha)=40.17 \mathrm{~cm}^{-1}$; crystal dimensions $0.18 \times 0.23 \times 0.31 \mathrm{~mm}$. Solution of the structure was as for complex 4. For 5308 unique observed reflections $(I>2 \sigma(I))$, collected at $295 \mathrm{~K}$ on a Rigaku AFC6S diffractometer $\left(6<2 \theta<140^{\circ}\right)$ and corrected for absorption, the final conventional $R$ was 0.098 (wR2 $=0.236$ ). The final difference map showed a residual peak of $2.7 \mathrm{e} \AA^{-3}$ in a position inconsistent with the aromatic rings $\mathrm{C} 21 \cdots \mathrm{C} 26$ and $\mathrm{C} 71 \cdots \mathrm{C} 76$. A sound discussion concerning bond distances and angles within the complex is prevented due to the relatively low accuracy of the actual refinement. See the Supporting Information for more details.

(16) The ${ }^{1} \mathrm{H}$ NMR spectra of 9 and 10 show broad resonances for substituents of the oxazoline ring and the coordinated THF. Similarly the ${ }^{13} \mathrm{C}$ spectra display a broad signal for the benzylic $\mathrm{CH}_{2}$. A complete low-temperature investigation will be presented in a forthcoming paper.

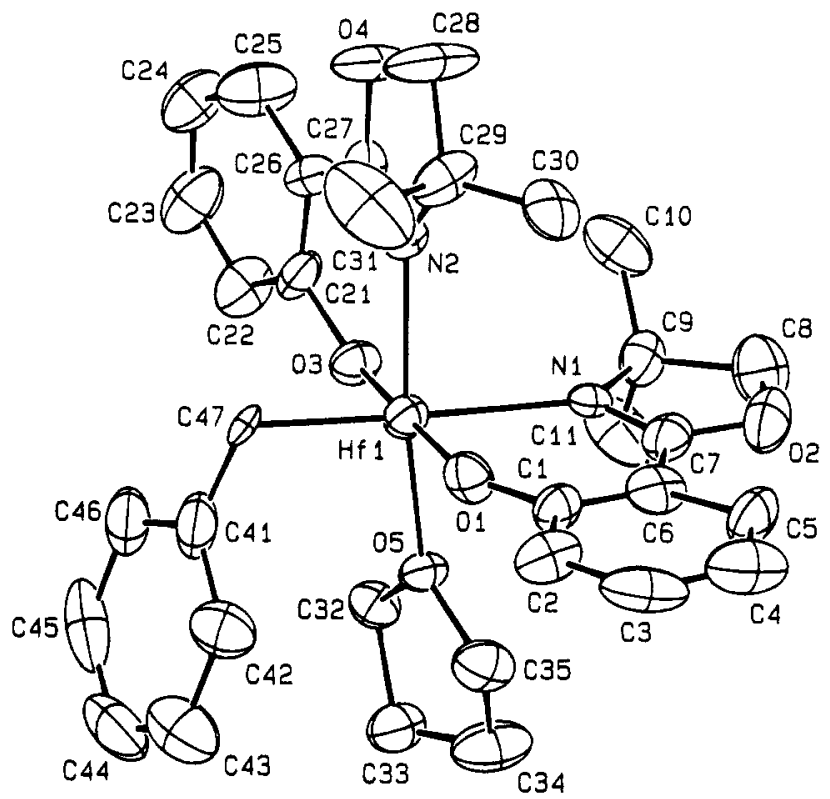

Figure 2. ORTEP drawing of complex 10 (30\% probability ellipsoids). Selected bond distances $(\AA)$ and angles (deg): Hf1-01, 2.005(14); Hf1-03, 1.987(14); Hf1-O5, 2.177(10); Hf1-N1, 2.342(14); Hf1-N2, 2.234(12); Hf1-C47, 2.231(15); N1-Hfl-C47, 165.3(6); O5-Hf1-N2, 161.2(5); O3$\mathrm{Hf1}-\mathrm{N} 2,81.3(5)$; O3-Hf1-O5, 83.8(5); O1-Hf1-N2, 101.5(5); O1-Hf1-O5, 92.5(5); O1-Hf1-O3, 174.5(6); Hf1-O1$\mathrm{C} 1,146.4(13)$; Hf1-O3-C21, 136.7(12).

modified (hydroxyphenyl)oxazoline ligands are accessible using methodologies developed for cationic metallocene derivatives. Future studies will concentrate on using such chiral $\mathrm{d}^{0}$ complexes for promoting catalytic or stoichiometric reactions in organic synthesis. ${ }^{18}$ Furthermore, we believe that the class of ligands we report herein may prove valuable in the development of stereoselective polymerization catalysts.

Acknowledgment. We would like to thank the "Fonds National Suisse de la Recherche Scientifique" (Grant No. 20-40268.94) and Ciba-Geigy Co. (Basel, Switzerland) for financial support.

Supporting Information Available: Tables giving experimental details associated with data collection, fractional atomic coordinates, thermal parameters, bond distances and angles, Figure $\mathrm{S} 1$ for complexes 4 and 10, a figure showing molecule $B$ of complex 4, and text giving spectroscopic and analytical data for complexes 5-7 (15 pages). Ordering information is given on any current masthead page.

\section{OM950503R}

(17) Preparation of 8 in toluene solution: to a solution of $4(1.56 \mathrm{~g}$, $2.39 \mathrm{mmol})$ in toluene $(50 \mathrm{~mL})$ at $-78{ }^{\circ} \mathrm{C}$ was added $\mathrm{HNEt}_{3}{ }^{-} \mathrm{BPh}_{4}{ }^{-}$ $(0.31 \mathrm{~g}, 0.71 \mathrm{mmol})$, and the yellow mixture was warmed to room temperature. Ethylene $(1 \mathrm{~atm})$ was added, and the solution was stirred for I day at room temperature. The mixture was quenched with $\mathrm{MeOH} /$ $\mathrm{HCl}(2 \mathrm{M})$, and the white-gray solid was collected, washed with $\mathrm{MeOH}$, and filtered $(7.0 \mathrm{~g})$.

(18) We have synthesized $\mathrm{Zr}(\mathrm{Oxa})_{2} \mathrm{OR}^{+} \mathrm{BPh}_{4}{ }^{-}(\mathrm{R}=$ diacetone- $\alpha$ glucose), which shows low activity in the Mukaiyama aldol reaction: Cozzi, P. G.; Floriani, C. Unpublished results. 